\title{
Analysis of a Glycinergic Inhibitory Pathway in the Cat Retina
}

\author{
H. Wässle, I. Schäfer-Trenkler, and T. Voigt \\ Max-Planck-Institut für Hirnforschung, D-6000 Frankfurt 71, West Germany
}

\begin{abstract}
Incubation of cat retinas with ${ }^{3} \mathrm{H}$-glycine in vitro, followed by horizontal sectioning and autoradiography, showed labeling of $10-12 \%$ of bipolar cells and $45 \%$ of amacrine cells. To ascertain the effects of glycine-accumulating bipolar and amacrine cells on the response properties of retinal ganglion cells, in vivo iontophoretic studies were performed in the cat eye. Glycine inhibited all ganglion cells, and this action was blocked by strychnine. Aminophosphonobutyric acid (APB) suppressed ONganglion cells, but activated OFF-ganglion cells. The influence of APB upon OFF-ganglion cells could be completely blocked by strychnine. In the mudpuppy, APB suppressed ON-bipolar cells without affecting OFF-bipolar cells and without direct effects on other retinal neurons (Slaughter and Miller, 1981, 1985). If APB has the same mode of action in the cat retina, the present results suggest a glycinergic inhibitory input of the $O N$-channel upon OFF-ganglion cells.
\end{abstract}

Autoradiographic analysis of retinas from a range of species including man, rabbit, cat, rat, pigeon, goldfish, and frog (Brunn and Ehinger, 1972; Ehinger and Falck, 1971; Kleinschmidt and Yazulla, 1984; Marc and Lam, 1981; Marshall and Voaden, 1974) indicates that glycine is localized within the inner nuclear layer (Berger et al., 1977). In addition, most of these earlier reports suggest glycine uptake is specific to amacrine cells. In goldfish retina, glycine was taken up into cells, which were postsynaptic to horizontal cells and probably presynaptic in the inner plexiform layer (Marc and Liu, 1984). Recently, more evidence has accumulated from studies in cat and man that suggests that certain bipolar cells have a high-affinity uptake of ${ }^{3} \mathrm{H}$-glycine (Frederick et al., 1984; Marc and Liu, 1985; McGuire et al., 1980, 1984a, b; Pourcho, 1980; Sterling, 1983).

In the cat retina, the inner nuclear layer contains at least four types of neurons (horizontal, bipolar, amacrine, and interplexiform cells) that occur in many morphologically distinct classes. Over most of the retina, the inner nuclear layer has a thickness of only 3-4 cell bodies. Therefore, in vertical sections it is difficult to encounter all those cells in a single section. Horizontal scetioning of the inner nuclcar layer displays morc cclls, which facilitates recognition of the different cell types (Marc, 1982). Therefore, in this study, following the uptake of radioactively labeled glycine, horizontal semithin sections through the cat retina were taken (Polley and Walsh, 1984) and prepared for autoradiography. From serial sections, the inner nuclear layer could be reconstructed and the type and proportion of neurons that accumulated glycine determined.

\footnotetext{
Received Jan. 29, 1985; revised June 24, 1985; accepted July 31, 1985.

We wish to thank Felicitas Boij for skillful technical assistance, Iringard Odenthal for valuable secretarial services, and Joan Dann for critically reading and greatly improving the English manuscript.

Correspondence should be sent to Heinz Wässle, Max-Planck-Institut für Hirnforschung, Abteilung Neuroanatomie, Deutschordenstrasse 46, D-6000 Frankfurt/ M. 71, F.R.G.

Copyright $\odot 1986$ Society for Neuroscience $0270-6474 / 86 / 020594-11 \$ 02.00 / 0$
}

Recently, McGuire et al. (1984a, b) have postulated a mechanism (the "push-pull hypothesis") that explains the center response of ganglion cells by excitatory and inhibitory bipolar cell input. Figure $1, A, B$ shows the wiring diagram proposed by McGuire et al. $(1984 \mathrm{a}, \mathrm{b})$ : ON-center ganglion cells receive an excitatory input from ON-bipolar cells and an inhibitory glycinergic input from OFF-bipolar cells. OFF-center ganglion cells are excited by OFF-bipolar cells and receive a glycinergic inhibition from ON-bipolar cells. Figure $1 C$ shows another possible pathway for such crosstalk between $\mathrm{ON}$ - and OFF-channels: ON-bipolar cells have an excitatory input onto an amacrine cell, which in turn inhibits an OFF-center ganglion cell using glycine as transmitter. A similar pathway could also be postulated for OFF-bipolar cells.

It has been shown that glycine exerts a powerful inhibition of all ganglion cells in the cat retina (Bolz et al., 1985a). Aminophosphonobutyric acid (APB) has been described in the mudpuppy retina as a specific blocker of the light response in $\mathrm{ON}$ bipolar cells without affecting OFF-bipolar cells (Slaughter and Miller, 1981, 1985). In the cat, APB suppressed the light response of ON-ganglion cells but raised the firing rate of OFFganglion cells (Bolz et al., 1984; Horton and Sherk, 1984; Sherk and Horton, 1984). A similar effect of APB on the discharge rate of rabbit ganglion cells has also been described (Massey et al., 1983).

Figure 1, $B, C$ offers a possible explanation for the unexpected activation of OFF-ganglion cells by APB: the suppression of inhibitory influences from ON-bipolar cells by APB might result in disinhibition and hence in a raised firing rate of OFF-ganglion cells. Since this inhibitory input would be glycinergic, either directly mediated by a glycinergic bipolar cell (Fig. $1 B$ ) or by an interposed glycinergic amacrine cell (Fig. 1C), it should be blocked by strychnine, which is a powerful and specific antagonist to glycine in the cat retina (Bolz et al., 1985a). Therefore, application of APB in the presence of strychnine should no longer influence OFF-ganglion cell discharges.

In the present study, extracellular recordings from ganglion cells of the cat retina were taken using multibarrcl clcctrodes. The action of APB iontophorized onto OFF-ganglion cells, and its interaction with the simultaneous application of strychnine, was studied in detail.

The present paper is not a study of glycinergic inhibition and its influence on ganglion cell responses in general. We have described this elsewhere (Bolz et al., 1985a). Here we focus on the question of whether the hypothesis that ON-bipolar cells have an inhibitory influence on OFF-center ganglion cells (Fig. $1, B$ and $C$ ) is consistent with our experiments on iontophoresis.

\section{Materials and Methods}

\section{Autoradiography}

Six young cats (11-14 weeks) were deeply anesthetized with Nembutal and the eyes enucleated. An eye was transferred into a Petri dish con- 
A

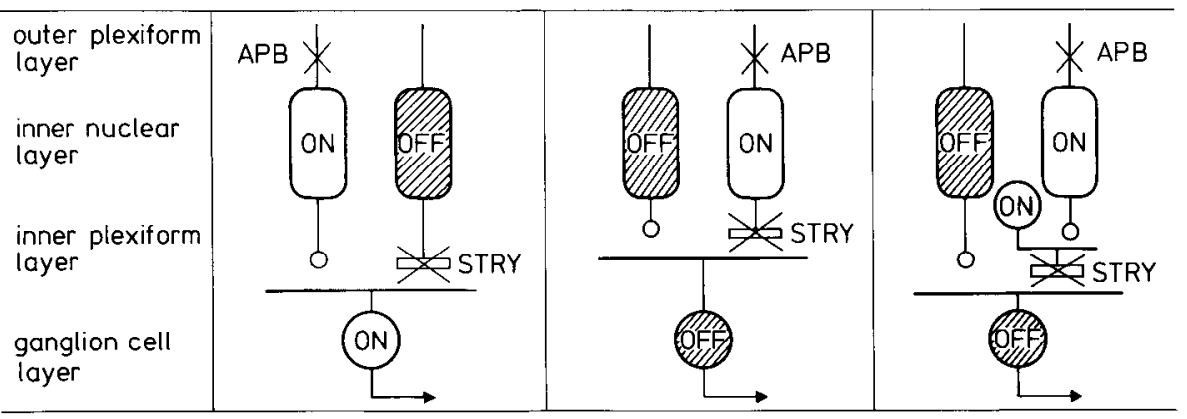

Figure 1. "Push-pull" hypothesis to explain excitatory and inhibitory interaction between bipolar and ganglion cells in the cat retina (McGuire et al., 1984a). $A$, An ON-center ganglion cell which gets excitatory input from depolarizing bipolar cells (ON-bipolar cells) and a glycinergic inhibitory input from hyperpolarizing bipolar cells (OFF-bipolar cells). B. An OFF-center ganglion cell which is excited by OFF-bipolar cells and inhibited by ON-bipolar cells. $C$, Alternative circuitry for an OFF-center ganglion cell. It does not receive a direct inhibition from an ON-bipolar cell, but is inhibited by an interposed amacrine cell. An identical pathway could also be postulated for ON-center ganglion cells. Application of $A P B$ would block $(\times)$ specifically ON-bipolar cells; application of strychnine $(S T R Y)$ would block $(\times)$ the glycinergic inhibition between bipolar or amacrine and ganglion cells.

taining Krebs' bicarbonate solution saturated with carbogen (Lee and Iversen, 1981). The anterior segment and vitreous were dissected. The eyecup was incubated for $30 \mathrm{~min}$ in the solution at $38^{\circ} \mathrm{C}$; it contained ${ }^{3} \mathrm{H}$-glycine (specific activity $44.2 \mathrm{Ci} / \mathrm{mmol}$ ) at a concentration of $10^{-6} \mathrm{M}$. Subsequently, the retinas were fixed in $1.5 \%$ glutaraldehyde, $1 \%$ paraformaldehyde in $0.1 \mathrm{M}$ phosphate buffer ( $\mathrm{pH} 7.4)$. After fixation, the retina was dissected from the eyecup in physiological saline. Radial cuts were made in the retina to allow it to be flattened between filter paper on a slide. Subsequently it was dehydrated and embedded flat in 2 hydroxymethylacrylate, as described by Polley and Walsh (1984). Flat sections of $3 \mu \mathrm{m}$ were taken on a microtome (Jung, Ultracut 1150) using a glass knife ( $38 \mathrm{~mm}$ wide). Sections were mounted on glass slides, coated with photoemulsion (Kodak, NTB2) and exposed for 10-14 d in the dark at $4^{\circ} \mathrm{C}$. They were developed in D-19, fixed in Rapid Fix and counterstained with cresyl violet.

\section{Analysis of autoradiographs}

Despite flattening, the retina contains crinkles; hence sections never pass through only one layer. Therefore, to produce a complete view of the inner nuclear layer, plots from up to 10 serial sections were made from the microscope with the aid of a camera lucida. The rough topography of the sections was drawn using a $\times 16$ objective at a final magnification of $\times 160$. Drawings of parts of the section passing through the inner nuclear layer were drawn with the aid of a $\times 100$ objective at a final magnification of $\times 1000$.

\section{Electrophysiology}

Four adult cats, weighing $2.2-4 \mathrm{~kg}$, were anesthetized with Halothane $(2-4 \%)$ in a $2: 1$ mixture of nitrous oxide and carbogen. The nitrous oxide was later supplemented with pentobarbitone $(1 \mathrm{mg} / \mathrm{kg} \mathrm{hr})$ in the infusion solution and Halothane was then omitted. The level of anesthesia was checked by monitoring the EEG. The animals were paralyzed and artificially respirated with the parameters of respiration adjusted to produce an end-tidal $\mathrm{CO}_{2}$ of $4 \%$. The body temperature was maintained at $38.0^{\circ} \mathrm{C}$.

The cat was placed in a stereotaxic headholder. The left eye was sewn to a ring at the limbus. A guard needle of $2 \mathrm{~mm}$ diameter was inserted into the vitreous through which the recording electrode was advanced onto the retina. A detailed description of the technique is given elsewhere (Bolz et al., 1982, 1985a; Peichl and Wässle, 1979).

\section{Electrodes}

Seven-barreled glass tubing (1.2 mm O.D.) was used to make a special tungsten-in-glass microelectrode (Bolz et al., 1984; Levick, 1972). The micropipettes were drawn on a standard puller and the tip broken back to a diameter of 4-5 $\mu \mathrm{m}$. An electrolytically sharpened tungsten wire was pushed through the central barrel until it protruded $12-15 \mu \mathrm{m}$ from the tip. The wire at the other end was glued to the glass with DeKhotinsky's cement. The surrounding barrels, each with an inner filament, were filled with drug solutions using a Hamilton syringe. Plati- num-iridium wires were inserted and the barrels were sealed with DeKhotinsky's cement.

\section{Ganglion cell classification}

Most ganglion cells encountered had concentric receptive fields and were of two types: brisk-sustained (X) and brisk-transient (Y). Cells of other types were occasionally recorded but not analyzed in detail.

As fully described by Cleland and Levick (1974a, b), several optical tests (response to standing contrast, periphery effect, sensitivity to size, and speed of disk targets) permit unequivocal identification of brisk, concentric units. At the same eccentricity, brisk-transient (Y) cells have a receptive field-center diameter about three times larger than brisksustained (X) cells (Peichl and Wässle, 1979).

\section{Optical stimulation and data analysis}

Center responses were evoked by a light spot congruent with the mapped receptive field center, and surround responses were evoked by a light annulus with an inner diameter matched to the center size and an outer diameter of $20^{\circ}$. The stimuli appeared as increments of $0.1-25 \mathrm{~cd} / \mathrm{m}^{2}$ on a homogeneous background of $2-100 \mathrm{~cd} / \mathrm{m}^{2}$. Some OFF-center cells were tested using black spot stimulation. The light stimuli were flashed on and off at $512 \mathrm{msec}$ intervals. Responses to 16 or 32 presentations of the stimulus were averaged by the computer as post-stimulus time histograms (PSTH) with a bin width of $15 \mathrm{msec}$. The integrated spike count over a single stimulus cycle $(1024 \mathrm{msec})$ was also continuously recorded.

\section{Iontophoresis in the retina}

All drugs were iontophoresed by means of a Neurophore BH-2 current source. The resistance of the drug-filled barrels varied between 20 and $60 \mathrm{M} \Omega$, depending on the drug and the tip size. Holding currents up to $40 \mathrm{nA}$ were sometimes used, but usually $10 \mathrm{nA}$ proved sufficient. Currents up to $50 \mathrm{nA}$ were used to eject the drugs. APB, 2-amino-4-phosphonobutyrate (Calbiochem) was made up in a $0.1 \mathrm{M}$ solution and adjusted to $\mathrm{pH} 7$ with $\mathrm{NaOH}$. All other substances were made up in physiological saline $(165 \mathrm{~mm} \mathrm{NaCl})$ and adjusted with $\mathrm{HCl}$. These were $n$-methylbicuculline bromide (Cambridge Research Biochemical), 2.5 mM at pH 3; strychnine (Serva), $2.5 \mathrm{~mm}$ at pH 3; and glycine (Sigma), $0.1 \mathrm{M}$ at $\mathrm{pH} 3$.

The position of the electrode could be backprojected onto the screen by the aid of a fundus camera (Zeiss) and if it was found within the mapped receptive field center, it was concluded that the unit was recorded from the cell body or dendrites (Peichl and Wässle, 1983). Recordings from axons, in which the electrode tip and the receptive field were separated, were discarded, as drugs ejected would not reach the synaptic sites of the cell. Most recordings were aimed at the raphe region of the temporal retina, where axon bundles are absent.

For the present study, 32 ganglion cells (14 ON-center and 18 OFFcenter cells) were analyzed in detail to test the interaction of APB, glycine, and strychnine. 

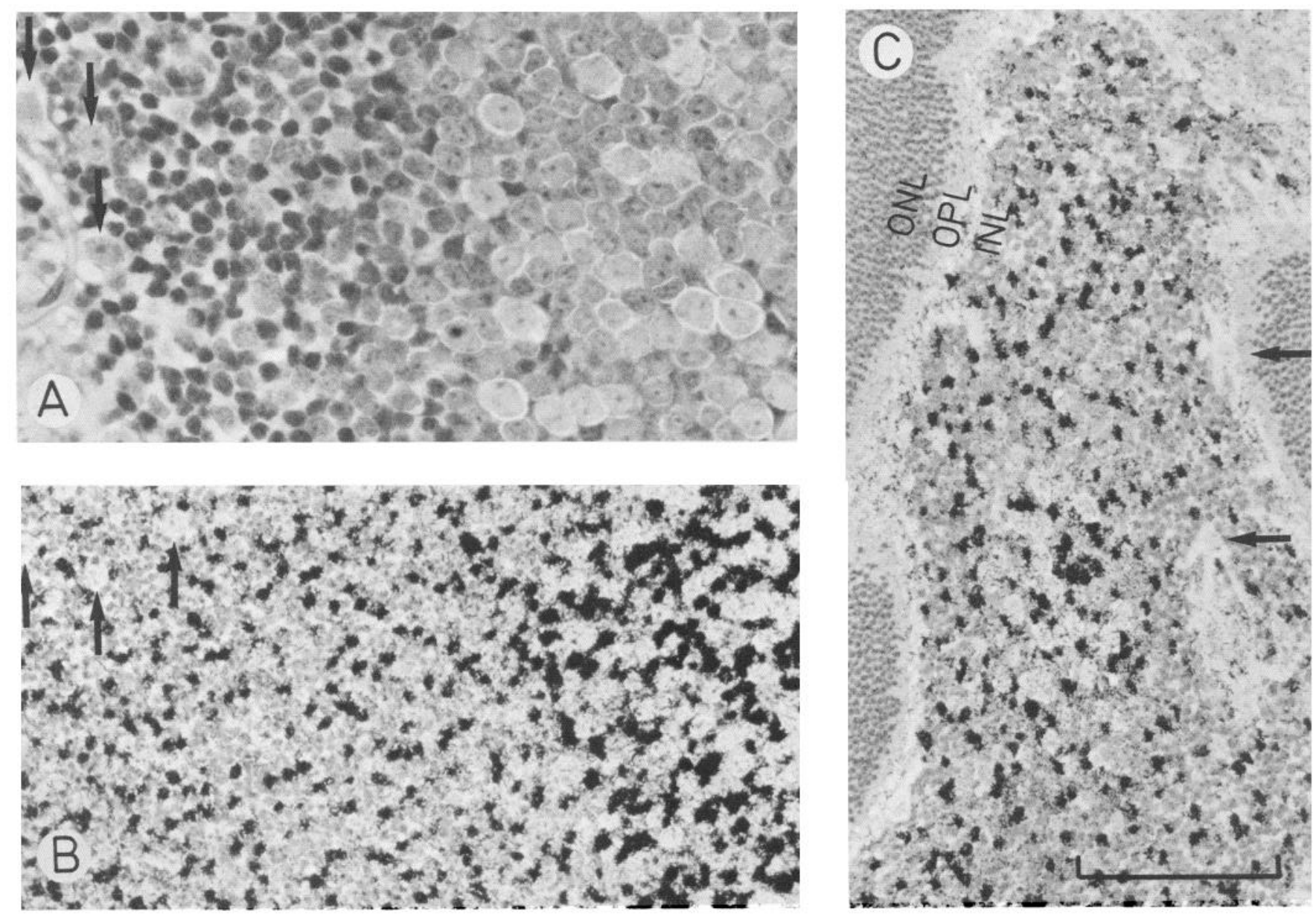

Figure 2. Micrographs of $3 \mu \mathrm{m}$ thick horizontal sections through the inner nuclear layer (INL) of the cat retina. $A$, Slightly oblique section illustrating the different cell types of the INL. The right half is occupied by amacrine cell bodies; the left half shows bipolar cells. On the left corner the outer plexiform layer appears and a small blood vessel can be seen. The three arrows point to horizontal cells. $B$, Autoradiogram of a slightly oblique section through the INL. In the right third, labeled and unlabeled amacrine cells can be seen; the left two-thirds are occupied by labeled and unlabeled bipolar cells. The three arrows point to unlabeled horizontal cells. $C$, Autoradiogram of a section passing through the inner nuclear layer $(I N L)$, where the retina has a slight fold. In the center, the section passes through the amacrine cell layer, which is surrounded by bipolar cells, the outer plexiform layer $(O P L)$, and the outer nuclear layer $(O N L)$. The two arrows point to A-type horizontal cells, whose star-shaped dendritic fields are apparent. The scale represents $50 \mu \mathrm{m}$ in $A$ and $100 \mu \mathrm{m}$ in $B$ and $C$.

\section{Results}

Cell types in the inner nuclear layer

Vertical sections illustrate the layering of the retina quite well, but if cell types within a single layer have to be investigated, the flat view in horizontal sections is more appropriate. Since the cat retina is up to $20 \mathrm{~mm}$ wide and the individual layers are only 10-30 $\mu \mathrm{m}$ thick, perfect horizontal sections are possible only in small areas. However, slightly oblique sections have the advantage of permitting identification of the layering, in addition to displaying sufficient cells within a single layer to study them in detail.

In Figure $2 A$, a section through the inner nuclear layer (INL) illustrates the cell types present and their relative position within that layer. The plane of the section is such that the right half cuts through the amacrine cells close to the inner plexiform layer, while the left half cuts through the bipolar and horizontal cells close to the outer plexiform layer. There is a clear difference in cell body and nuclear size between horizontal, bipolar, and amacrine cells, which, together with their differing position within the INL, makes classification possible. It was not possible to recognize the interplexiform cells, which are located between the amacrine cells (Boycott et al., 1975; Kolb and West, 1977;
Nakamura et al., 1980). Bipolar cells (left half of Fig. 2A) seem to occur in two varieties. About half of them have a small, darkstaining nucleus, densely packed with chromatin; the others have a slightly larger nucleus which is more lightly stained. It cannot be determined whether they might represent rod or cone bipolar cells (Boycott and Kolb, 1973; Kolb, 1977; McGuire et al., 1984a; Nelson and Kolb, 1983). Amacrine cells (right half of Fig. $2 A$ ) also constitute different classes (Kolb and Nelson, 1981; Kolb et al., 1981). A variety with a large pale nucleus surrounded by pale cytoplasm is very obvious. The few horizontal cells (arrowed) on the left of Figure $2 A$ have a large pale nucleus with a distinct nucleolus surrounded by a halo of lightly stained cytoplasm. Sometimes thick dendrites can be seen leaving the cell body (see arrows in Fig. 2C). Throughout the INL, polygonal dark staining profiles of differing size can be observed; they are probably processes and cell bodies of Müller cells. At the outer border of the INL, sparsely distributed dark violetstained nuclei can be seen; these are probably nuclei of microglia cells (Boycott and Hopkins, 1981).

\section{Uptake of ${ }^{3} \mathrm{H}$-glycine by cells of the INL}

After an exposure of 10-14 d, heavy labeling of single cells with patches of silver grains was observed. Figure $2 B$ shows, at lower 
magnification, a section through the INL comparable to that in Figure $2 A$. Dense labeling of amacrine cells is observed, a considerable proportion of bipolar cells is also labeled, but no horizontal cells (arrowed) seem to have taken up ${ }^{3} \mathrm{H}$-glycine. About $10 \%$ of bipolar cells and $40 \%$ of cells in the amacrine layer (amacrine + interplexiform cells) have taken up ${ }^{3} \mathrm{H}$-glycine in the section of Figure $2 B$.

\section{Horizontal, bipolar, and amacrine cells}

A more detailed analysis of the labeling percentage was performed for the retinal field illustrated in Figures $2 C$ and 3 . Ten consecutive sections could be lined up exactly and it was possible to reconstruct perfect flat views of the inner nuclear layer. The plane of section in Figure $2 C$ is such that amacrine cells can be seen in the center, surrounded progressively by bipolar cells, the outer plexiform layer, and, at the extreme border of the figure, photoreceptor cells. Figure $3 A$ is a camera lucida drawing of the same field, but the plane of section was $6 \mu \mathrm{m}$ further towards the photoreceptors; hence mainly bipolar cells are present. Figure $3 B$ was taken $9 \mu \mathrm{m}$ further towards the ganglion cell layer than Figure $3 A$, and mainly amacrine cells are labeled in the center of the drawing. Perfect flat views of the square indicated in Figure 3, $A$ and $B$ are constructed in Figure 3, $C-E$. Figure $3 C$ shows the horizontal cell nuclei found at the outcr edge of the INL. They form a regular mosaic, with a density of 1050 cells $/ \mathrm{mm}^{2}$. It would be possible in this material (arrows in Fig. 2C) to recognize A- and B-type horizontal cells (Boycott et al., 1978) but this was not the aim in the present study. No horizontal cells were found to be labeled. Comparison with previous density values from whole mounted retinas with minimal shrinkage (Wässle et al., 1978) indicates that the present material was shrunken by a factor of 0.6 .

Figure $3 D$ shows the bipolar cell layer cutting through the center of the INL. Altogether, 724 bipolar cells were encountered, of which 83 were labeled; therefore, $11.5 \%$ of these cells have taken up ${ }^{3} \mathrm{H}$-glycine. Patches of silver grains were accepted as definite cell labeling only when overlying a Nissl-stained nucleus. Bipolar cells often appear pear-shaped in vertical semithin sections, with their long axis oriented radially in the INL and the primary dendrite pointing towards the OPL. Only the nucleus, which has an average diameter of $7 \mu \mathrm{m}$, stained in our material, and this fills the whole cross-sectional area at the widest point of the cell body. In the $3 \mu \mathrm{m}$ sections of the present study, an individual bipolar cell nucleus could be observed in up to three consecutive sections. This was used for exactly lining up the sections.

From the 10 serial sections through the INL, the total number of bipolar cells in that retinal area can be given. Applying the Abercrombie (1946) correction, which accounts for the fact that an individual cell is counted in consecutive sections, we estimated a density of 51,400 bipolar cells $/ \mathrm{mm}^{2}$.

A single class of rod bipolar cell is described in the cat retina (Boycott and Kolb, 1973) and as many as eight types of cone bipolar cells can be distinguished (Famiglietti, 1981; Kolb et al., 1981; McGuire et al., 1984a; Nelson and Kolb, 1983). While it is impossible, from the present material, to recognize the different varieties of bipolar cell, a possible estimate of the minimum number of rod bipolar cells can be given on the basis of their rod contacts, which approximately equal 15 (Kolb and Nelson, 1983). The rod density at $7 \mathrm{~mm}$ eccentricity is about $450,000 \mathrm{rods} / \mathrm{mm}^{2}$ (Steinberg et al., 1973). Therefore, the minimum rod bipolar density required to ensure that every rod feeds into at least one bipolar cell would be about 30,000 cells/ $\mathrm{mm}^{2}$. Thus, approximately half of all bipolar cells would be rod bipolar, and the other half cone bipolar cells.

Altogether, $11.5 \%$ of all bipolar cells showed uptake of exogenous ${ }^{3} \mathrm{H}$-glycine. McGuire et al. (1984a) did not observe glycine labeling of ultrastructurally identified rod bipolar cells.
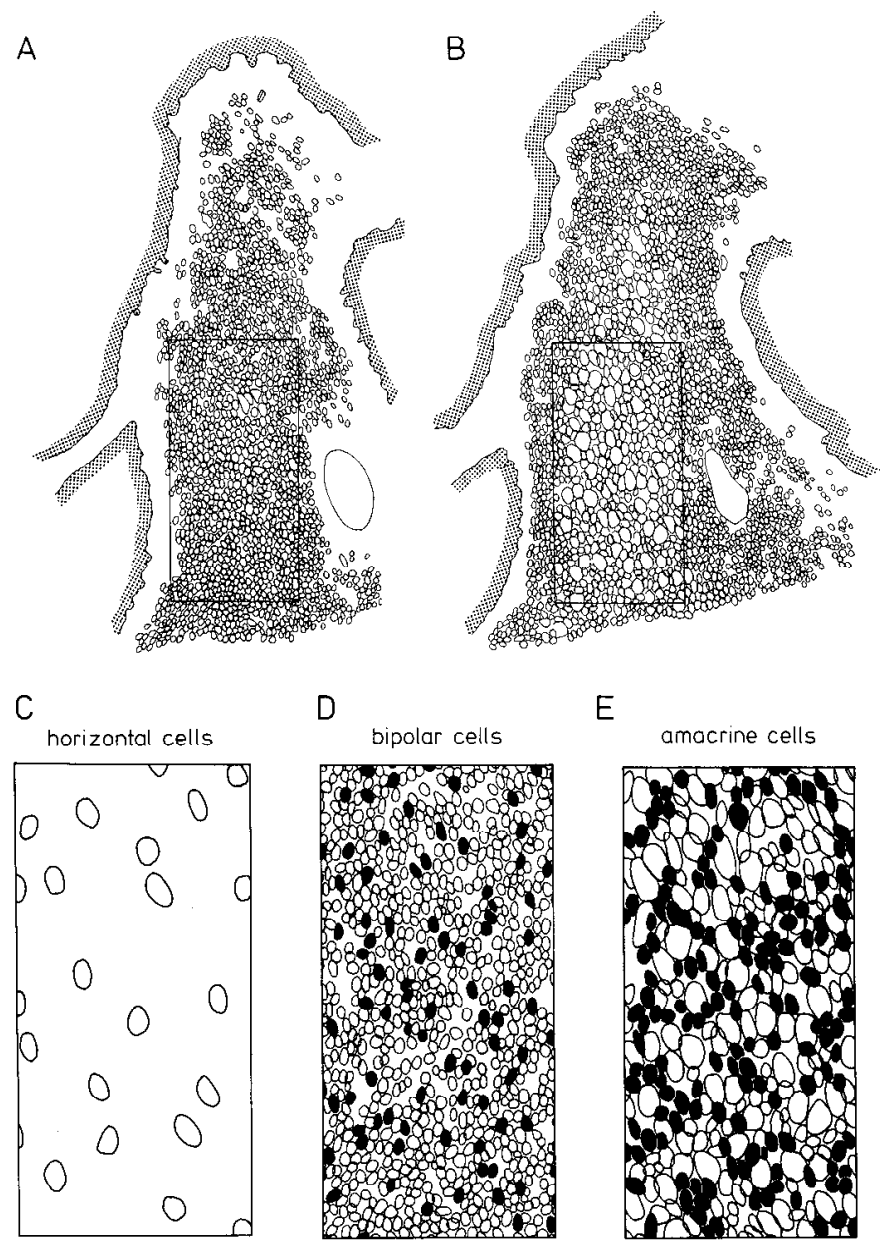

E

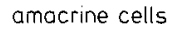

Figure 3. Reconstruction of perfect flat views of the inner nuclear layer (INL). A, Drawing of a section through the INL that cuts mainly bipolar cells. No labeling is indicated in this drawing. The hatched outline marks the border of the outer nuclear layer. $B$, Drawing of a section through the INL taken $9 \mu \mathrm{m}$ closer to the ganglion cell layer than the section in $A$. Mainly amacrine cells are seen in the center of the drawing. No labeling is indicated. For the square, $100 \times 200 \mu \mathrm{m}$ wide in $A$ and $B$, perfect flat views were constructed from several consecutive sections. The reconstructions show horizontal cells in $C$, bipolar cells in $D$, and amacrine cells in E. Filled profiles indicate labeled cells.

Therefore, considering cone bipolar cells separately, as many as $30 \%$ of them might take up ${ }^{3} \mathrm{H}$-glycine.

There was a gradient of the percentage labeling of bipolar cells within the INL. At the outer margin of the INL, less labeling was observed; in the middle of the INL, relatively more bipolar cells took up ${ }^{3} \mathrm{H}$-glycine. This might reflect differing proportions of rod and cone bipolar cells within the INL.

Amacrine cells are basically found as a single sheet of cell bodies at the border between the INL and IPL. Figure $3 E$ shows a reconstruction of cell bodies in the amacrine layer from the drawings of consecutive horizontal sections through the INL. It was possible, because of the large size of individual amacrine cells (up to $15 \mu \mathrm{m}$ ), to identify them in consecutive sections and reconstruct the total layer from five sections. There is a group of large cell bodies in Figure $3 E$ that did not take up ${ }^{3} \mathrm{H}$-glycine. These cells have a pale nucleus surrounded by a halo of cytoplasm. Mostly amacrine cells with smaller cell bodies were found to be labeled. The density of amacrine cells in Figure $3 E$ was $16,300 \mathrm{cells} / \mathrm{mm}^{2}$ and, of these, $46 \%$ were found to be labeled. Our estimate of $46 \%$ labeled amacrine cells is in excellent agreement with Pourcho's (1980) estimate of $43 \%$ from vertical sections. 
Figure 4. Effects of glycine (GLY) and strychnine (STRY) on the activity of an OFF-center brisk-sustained (X) cell during light stimulation. The continuous record indicates the number of spikes counted in $1025 \mathrm{msec}$ intervals; the bottom horizontal line indicates zero counts. The black horizontal bars show the time intervals of drug application. The strength of iontophoretic current (in $\mathrm{nA}$ ) and the applied drugs are indicated. The holding current for glycine was $-40 \mathrm{nA}$, and $-15 \mathrm{nA}$ for strychnine. This cell had an eccentricity of $8^{\circ}$ and its receptive field center was stimulated by a spot (40' diameter) of $25 \mathrm{~cd} / \mathrm{m}^{2}$ against a background of $3 \mathrm{~cd} / \mathrm{m}^{2}$. The post-stimulus time histograms (PSTH) from 32 stimulus presentations were collected at time periods indicated by the numbers in the continuous trace. The hatched bar under the PSTH indicates the $512 \mathrm{msec}$ period when the light was on; the open bar the 512 msec period when the light was off. Its height -40 spikes/sec.
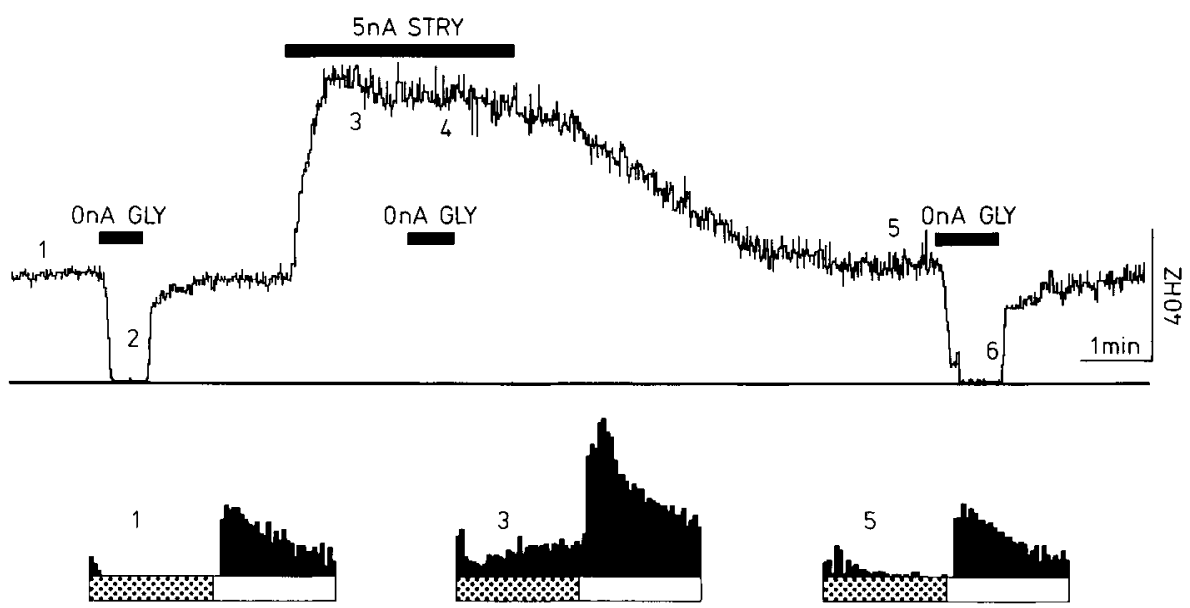

2
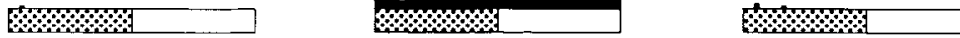

Sections at the outer margin of the amacrine layer displayed Müller cells (Polyak, 1941), which showed a dark violet homogeneous cytoplasm and surrounded amacrine cell bodies with polygonal profiles. We cannot exclude the possibility that some bipolar cell bodies might be included in the amacrine sample, if they were close to the IPL. A more serious problem is interplexiform cells, which we have almost certainly included in our amacrine sample. Like amacrine cells, they have larger cell bodies and lighter staining compared to bipolar cells, and in most cases their cell bodies are found close to the IPL (Boycott et al., 1975; Kolb and West, 1977; Nakamura et al., 1980). There is firm evidence in the cat that interplexiform cells accumulate exogenous ${ }^{3} \mathrm{H}-\mathrm{GABA}$ or ${ }^{3} \mathrm{H}-\mathrm{Muscimol}$ and constitute $2 \%$ of the neurons at the inner margin of the inner nuclear layer (Nakamura ct al., 1980; Pourcho and Goebel, 1983), and are therefore not distinguishable from amacrine cells, which introduces only a small error.

The density of horizontal cells was $1050 / \mathrm{mm}^{2}$, the bipolar cell density $51,400 / \mathrm{mm}^{2}$, and the amacrine density $16,300 / \mathrm{mm}^{2}$. Hence their relative frequency would be 1:50:15. We have not investigated changes of bipolar and amacrine cell density with eccentricity. For horizontal cells, it is known that there is a steep decrease of density from the central area towards the peripheral retina (Wässle et al., 1978). For one class of amacrine cells (AII) which was selectively stained by uptake of a fluorescent dye, a density range from 500 cells $/ \mathrm{mm}^{2}$ in the periphery to 5300 cells $/ \mathrm{mm}^{2}$ in the center was observed (Vaney, 1985). Another class of amacrine cells in the cat retina could be labeled with antibodies directed against cholinacetyltransferase (Schmidt et al., 1985) and their density increased from $280 \mathrm{cells} / \mathrm{mm}^{2}$ in the periphery to 2750 cells $/ \mathrm{mm}^{2}$ in the center. Therefore, it is quite likely that other classes of amacrine cells and bipolar cells show a comparable density gradient.

No ganglion cells took up glycine and only few displaced amacrine cells were found to be labeled. But there was a prominent labeling of astrocytes. The latter were unequivocally recognized on the basis of their small cell bodies-which are often found in the optic nerve fiber layer-their overall distribution which shows a peak density at the optic nerve head - and, finally, the orientation of their dendrites parallel to optic nerve fibers.

Both from vertical sections and from slightly oblique hori- zontal sections, an uneven labeling of the inner plexiform layer was apparent. The inner third of the IPL was only weakly labeled; the outer two-thirds, with the exception of a small band close to the INL, were heavily labeled. This pattern suggests that ${ }^{3} \mathrm{H}$-glycine is mainly accumulated by neurons ramifying in the ON- and OFF-sublaminae of the IPL but not in the inner third of the IPL, where rod bipolar cells terminate. Such a spatial segregation agrees with the termination of glycinergic bipolar cell axons (McGuire et al., 1984a) and has also been described by Pourcho (1980).

\section{Action of glycine}

Iontophoretically applied glycine and its antagonist, strychnine, influence the activity of all ganglion cells (Bolz et al., 1985a). The typical influence of these substances is illustrated for a brisksustained (X) cell in Figure 4, in which the neural activity was evoked by mesopic stimulation of the receptive field center. The numerals adjacent to the continuous integrated spike record indicate the time at which the correspondingly numbered poststimulus time histograms (PSTH) were collected. The average neural activity was about $50 \mathrm{~Hz}$ and the cell displays a PSTH (1) typical of an OFF-brisk-sustained (X) cell. Removing the holding current of $-40 \mathrm{nA}$ from the glycine barrel completely suppressed spike activity (2), an influence that was largely reversed within a few seconds after reapplying the holding current. In contrast, application of strychnine with $+5 \mathrm{nA}$ greatly increased spike activity. When glycine was ejected during strychnine application, neither the continuous record nor the PSTH (compare PSTH 3 and 4) shows any signs of glycine-induced suppression. After switching off strychnine, cell firing gradually returned to the original level and application of glycine completely suppressed the discharge as before.

The block of glycine suppression by strychnine cannot be attributed to an increase in discharge rate. For example, Figure 5 shows the influence of glycine, presented periodically in 25 sec cycles, on an ON-brisk-transient $(\mathrm{Y})$ and an OFF-brisksustained $(\mathrm{X})$ cell (left and right, respectively). A comparison of $A$ with $B$ and $C$ ' with $D$ indicates that bicuculline and strychnine increase spike activity by similar amounts. Nevertheless, the inhibitory action of exogenously applied glycine is uninfluenced by bicuculline and completely blocked by strychnine. 

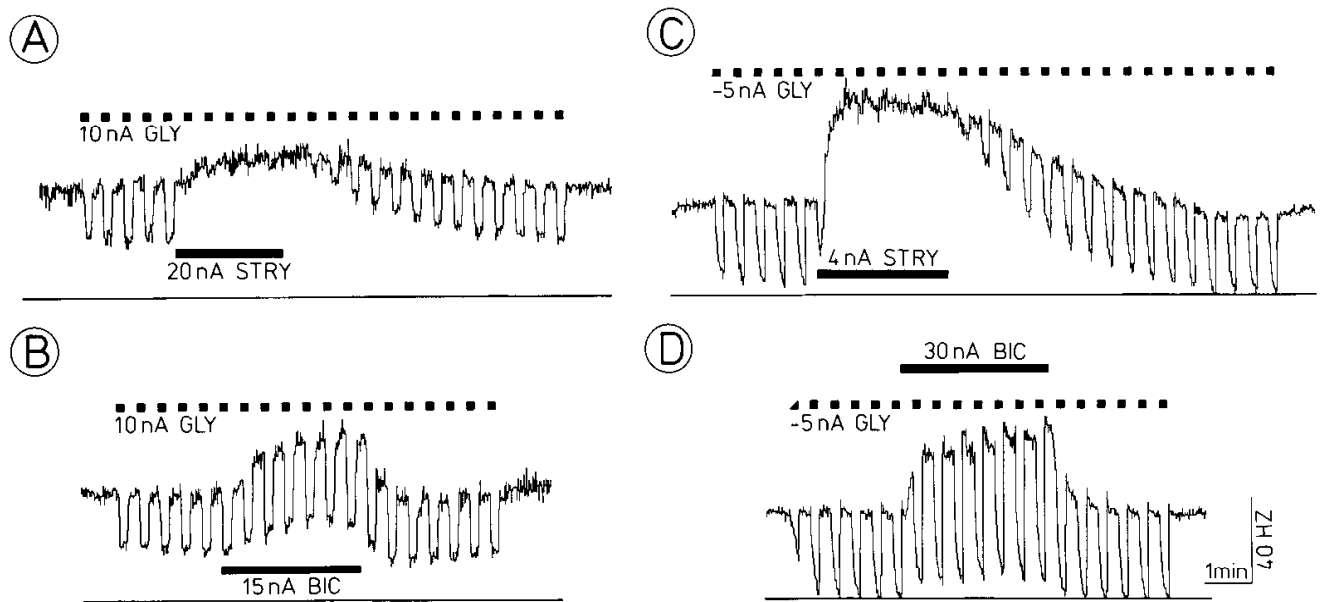

Figure 5. Influence of glycine (GLY), strychnine (STRY), and bicuculline (BIC) upon the discharge rates of two ganglion cells during light stimulation. The left tracings $(A, B)$ are from a brisk-transient $(\mathrm{Y})$ and the right tracings $(C, D)$ from a brisk-sustained $(\mathrm{X})$ cell. The number of spikes counted in $1024 \mathrm{msec}$ intervals is recorded by the continuous trace: the bottom horizontal line indicates zero counts. At the time indicated by the short bars, glycine was ejected periodically for $10 \mathrm{sec}$. The time periods of strychnine $(A, C)$ and bicuculline ejection $(B, D)$ are indicated by the labeled long bars. The receptive field centers of both cells were stimulated by light spots of $1.7^{\circ}$ diameter and $5 \mathrm{~cd} / \mathrm{m}^{2}\left(\right.$ left tracings) or $40^{\prime}$ diameter and $25 \mathrm{~cd} / \mathrm{m}^{2}$ (right tracings) against an ambient background of $3 \mathrm{~cd} / \mathrm{m}^{2}$. The holding current for glycine for the cell on the right was -40 $\mathrm{nA}$ and for other drugs, $-10 \mathrm{nA}$.

In summary, exogenous glycine exerts a powerful inhibition of all brisk types of cat retinal ganglion cells, which can be very effectively blocked by application of strychnine. Bicuculline could not block the glycinc action. We have shown elsewhere (Bolz et al., 1985b) that strychnine does not influence the GABAergic inhibition of ganglion cells.

\section{Action of $A P B$}

Iontophoretically applied APB suppressed the maintained activity of ON-ganglion cells and raised the maintained discharge rate of OFF-ganglion cells (Bolz et al., 1984). Figure 6 shows the continuous record of APB iontophoresis to illustrate the characteristic biphasic action of this drug. In the ON-center cell (A), ejection of APB effectively suppresses the firing rate within a few seconds. After termination of APB ejection, a remarkable "overshoot" in firing can be observed, from which the cell gradually returns to its original discharge rate. The response of UFFcenter cells $(B)$ shows an inverse behavior: application of APB raises the firing rate; following the termination of $A P B$ ejection, the cell is suppressed and slowly returns to the predrug firing level.

Figure 7 shows the interaction of APB application with strychnine and bicuculline during light stimulation for an ON-center brisk-sustained $(\mathrm{X})$ cell. As indicated in the continuous record and the corresponding histograms (PSTH 1, 2), APB suppressed the light-driven discharge. Application of strychnine raised the discharge rate but could not block the suppressive action of simultaneously ejected APB (PSTH 3,4). Ejection of bicuculline in addition to strychnine also did not block the APB effect (PSTH 5, 6).

A similar experiment with a representative OFF-center brisksustained (X) cell showed a remarkable difference (Fig. 8). Ejection of APB increased the firing of this cell. Ejection of strychnine also raised the firing rate of this OFF-cell, but in addition completely blocked the action of simultaneously applied APB.

The specific blocking of APB action caused by strychnine in OFF-center cells is further elaborated in Figure 9. In an ONcenter (Fig. 9A) and in an OFF-center (Fig. 9B) brisk-sustained cell, APB was periodically applied (eject $15 \mathrm{sec}$, pause $10 \mathrm{sec}$ ). The ON-cell firing $(A)$ was suppressed by APB ejection followed by an increase in firing when APB was stopped. Hence a periodic decrease and increase with respect to the predrug discharge rate is observed. During application of strychnine, the mean firing rate increases, but the modulation by APB still persists. The OFF-cell firing $(B)$ was raised by APB ejection and suppressed when APB was stopped. A periodic increase and decrease with respect to the predrug discharge rate is observed. When strychnine is ejected, the biphasic modulation of the firing rate by APB is completely blocked. After termination of strychnine, APB gradually becomes effective again.
(A)

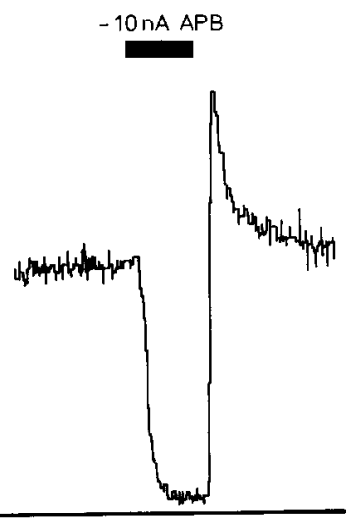

(B)

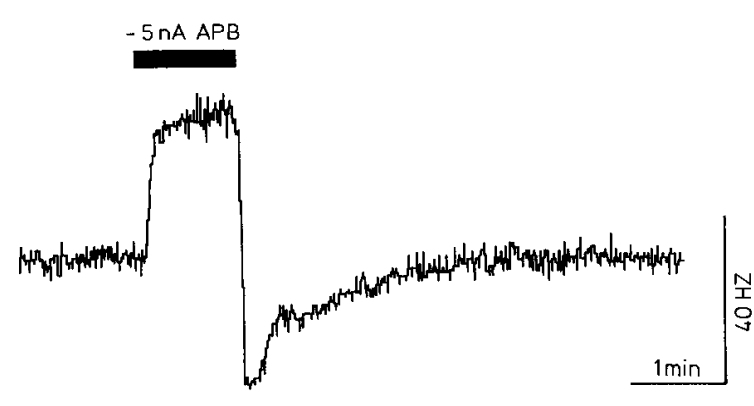

Figure 6. Influence of 2-amino-4phosphonobutyrate $(A P B)$ on the discharge rate of an $\mathrm{ON}$-center brisk-sustained (X) cell, $A$, and an OFF-center brisk-transient $(\mathrm{Y})$ cell, $B$. The cell in $A$ had a receptive field center diameter of $1^{\circ}$, which was stimulated with a light spot of $40^{\prime}$ and an intensity of $30 \mathrm{~cd} / \mathrm{m}^{2}$, at a background of $3 \mathrm{~cd} /$ $\mathrm{m}^{2}$. The cell in $B$ had a receptive field center diameter of $3^{\circ}$, and was stimulated with a light spot of $2.5^{\circ}$ (luminance $3 \mathrm{~cd} / \mathrm{m}^{2}$, background $1 \mathrm{~cd} /$ $\left.\mathrm{m}^{2}\right)$. Both cells were from an eccentricity of $10^{\circ}$. Other conventions as in Figure 4, holding current $10 \mathrm{nA}(A)$ and $8 \mathrm{nA}(B)$. 


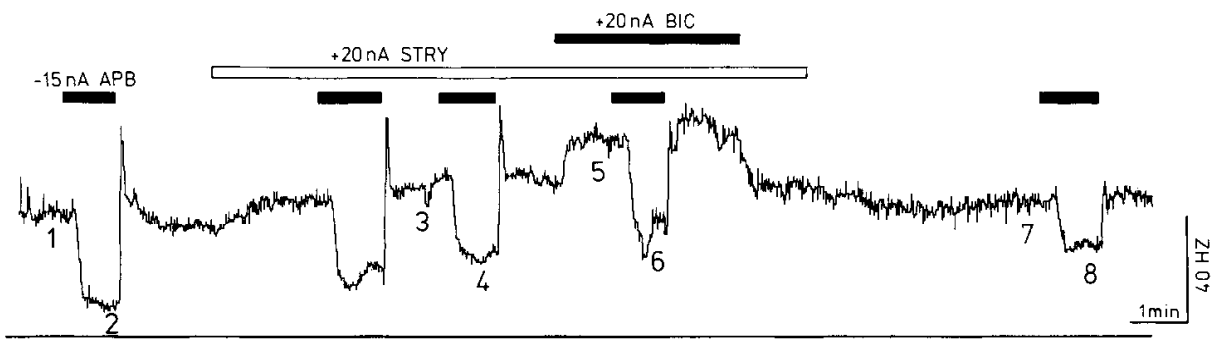

Figure 7. The influence of APB, strychnine (STRY), and bicuculline $(B I C)$ on the discharge rate of an $\mathrm{ON}$ center brisk-sustained $(\mathrm{X})$ cell. Conventions as in Figure 4. On all three drug barrels, a holding current of 10 nA was applied. The cell was stimulated with a light spot of $9 \mathrm{~cd} / \mathrm{m}^{2}$ on a background of $3 \mathrm{~cd} / \mathrm{m}^{2}$. The diameter of the light spot was $40^{\prime}$; the receptive field center diameter was $50^{\prime}$; eccentricity $4^{\circ}$.
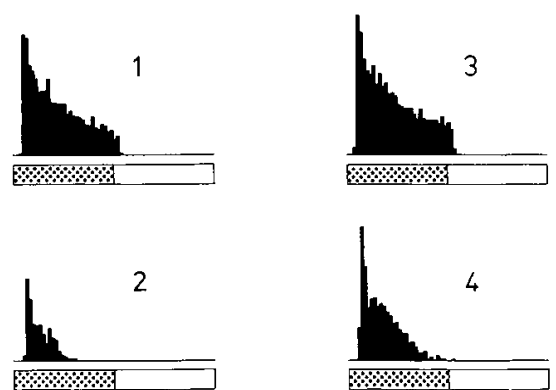

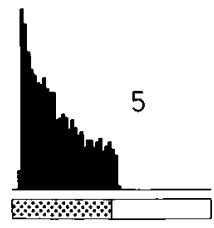

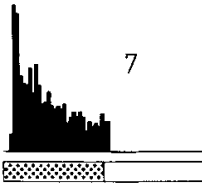
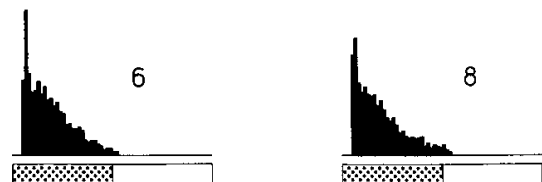

One might argue that strychnine increases the firing rate to saturation and therefore APB could not further increase the cell firing. This is ruled out by the recordings from an OFF-center brisk-transient $(\mathrm{Y})$ cell shown in Figure 9, $C$ and $D$. APB is periodically ejected (eject $10 \mathrm{sec}$, pause $15 \mathrm{sec}$ ) and either strychnine $(C)$ or $N$-methylbicuculline $(D)$ are added from two other barrels. While both drugs raised the cell firing by about equal amounts, only strychnine blocked the APB modulation.

It is also possible that APB acts in OFF-center ganglion cells by blocking glycinergic inhibition in general, and therefore increasing the discharge rate. If so, the blocking of APB action by strychnine could be explained by competition of the two drugs for glycine receptors. If all glycine receptors could be blocked by strychnine, APB could not exert any more action. This hypothesis is ruled out by the recordings in Figure 10. Application
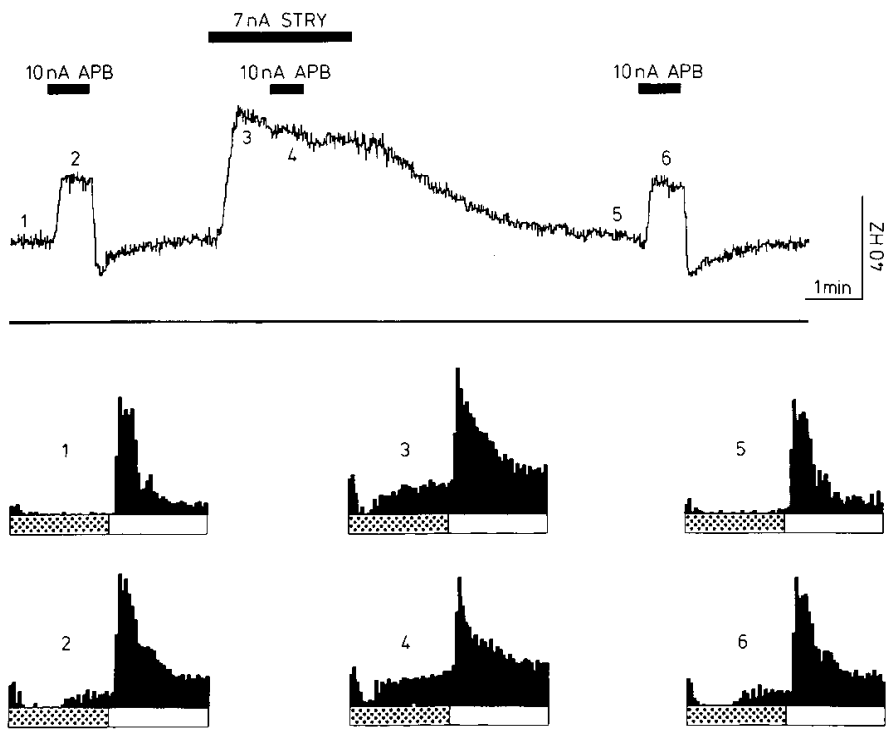

Figure 8. The influence of APB and strychnine (STRY) on the discharge rate of an OFF-center brisk-sustained (X) cell. Conventions as in Figure 4. The cell was stimulated with a light spot of $1^{\circ}$ diameter and $3 \mathrm{~cd} / \mathrm{m}^{2}$ luminance on a background of $1.5 \mathrm{~cd} / \mathrm{m}^{2}$. The receptive field center diameter was $1.2^{\circ}$; eccentricity was $9^{\circ}$. No holding current was necessary for strychnine; APB was retaincd with $10 \mathrm{nA}$ holding current. Note that strychnine completely blocks the APB. of glycine nearly completely suppressed the discharge rate (compare 1 and 2); ejection of APB greatly increased the firing without blocking glycinergic inhibition (compare 3 and 4 ).

In summary, exogenous APB decreases the firing rate of $O N$ center cells and increases the firing rate of OFF-center cells. The action of APB on ON-center cells cannot be blocked by strychnine or bicuculline; the action of APB on OFF-center cells is completely blocked by strychnine, but not by bicuculline.

\section{Discussion}

\section{Interpretation of $A P B$ and strychnine action}

In the mudpuppy and the rabbit retina, APB was found to be a specific blocker of ON-bipolar cells (depolarizing bipolar cells) (Bloomfield and Dowling, 1985a, b; Slaughter and Miller, 1981, 1985). In a previous study (Bolz et al., 1984) and in the present paper we have shown that, in the cat retina, APB not only suppresses $\mathrm{ON}$-center ganglion cell firing, but also raises the OFF-center ganglion cell discharge rate. Unfortunately we cannot decide where in the retinal network APB is acting in our iontophoresis experiment; this will be discussed later in detail. If one could assume, in analogy to the mudpuppy and the rabbit, that APB specifically blocks ON-bipolar cclls of the cat retina, how would one explain its effect on OFF-ganglion cells?

McGuire et al. (1984a, b) and Sterling (1983) presented evidence from an ultrastructural study that bipolar cells take up ${ }^{3} \mathrm{H}$-glycine and suggested that they might be inhibitory onto ganglion cells. They have postulated the "push-pull hypothesis" illustrated in Figure 1, $A, B$, which states that ON-ganglion cells might get excitatory input from $O N$-bipolar cells and inhibitory input from OFF-bipolar cells. Conversely, OFF-ganglion cells would be excited by OFF-bipolar cells and inhibited by $\mathrm{ON}-$ bipolar cells. Such wiring would sharpen the response of ganglion cells to a light stimulus. This does not mean that the same ON- (or OFF-) bipolar cell would contain an excitatory and an inhibitory transmitter; however ON-bipolar cells exciting ONganglion cells and ON-bipolar cells inhibiting OFF-ganglion cells are different classes. An alternative pathway is illustrated for OFF-ganglion cells in Figure $1 C$, where the ON-bipolar cell would provide an excitatory input into an amacrine cell, which then inhibits the OFF-ganglion cell.

According to these hypotheses (Fig. 1), blockage of ON-bipolar cells by APB would stop excitatory input into $\mathrm{ON}$-ganglion cells and their firing rate would decrease. Blockage of ON-bi- 

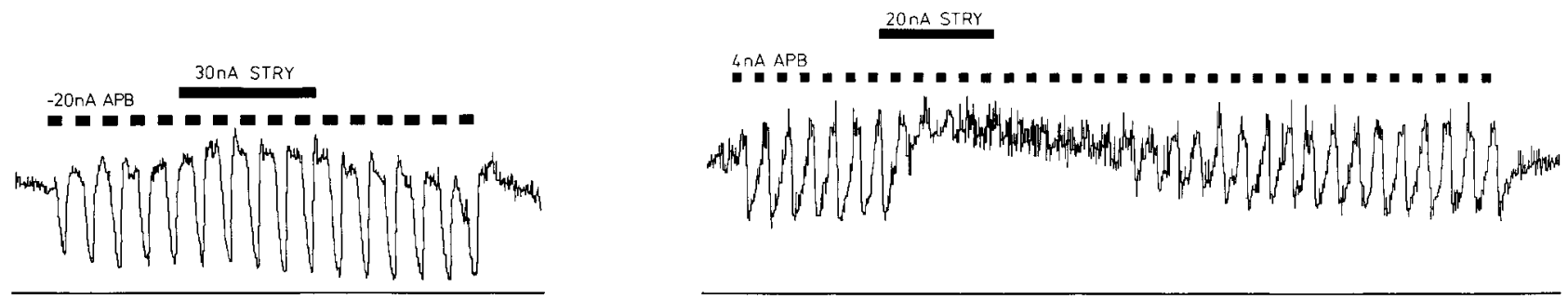

(B) OFF BRISK-SUSTAINED $(X)$

(D)
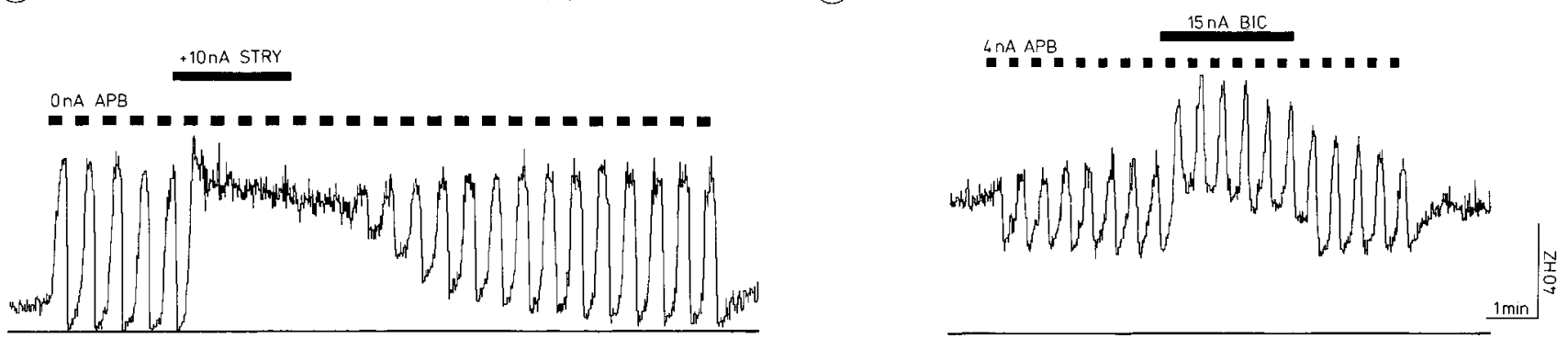

Figure 9. Periodic application of APB and its interaction with strychnine (STRY) and bicuculline (BIC). Conventions as in Figure 5. The recordings in $A$ are from the same ON-center brisk-sustained (X) cell as those in Figure 7, where further details are given. The recordings in $B$ are from an OFF-center brisk-sustained (X) cell during maintained discharge (receptive field center diameter: $50^{\prime} ;$ eccentricity, $4^{\circ} ;$ background, $3 \mathrm{~cd} / \mathrm{m}^{2}$ ). APB was switched from $9 \mathrm{nA}$ holding current to $0 \mathrm{nA}$ holding current. The records in $C$ and $D$ are from the same OFF-center brisk-transient (Y) cell during center stimulation (light spot diameter $2^{\circ}$, luminance $30 \mathrm{~cd} / \mathrm{m}^{2}$, background $3 \mathrm{~cd} / \mathrm{m}^{2}$ ). The receptive field center diameter was $2.5^{\circ}$; eccentricity was $6^{\circ}$. APB was switched periodically from $+9 \mathrm{nA}$ holding current to $-4 \mathrm{nA}$ ejecting current $(10 \mathrm{sec}$ eject, 15 sec pause). Bicuculline and strychnine were retained with a holding current of $10 \mathrm{nA}$. Notice that both strychnine (in $C$ ) and bicuculline (in $D$ ) raise the firing rate of this cell, but only strychnine blocks the APB action.

polar cells by APB would also abolish their inhibitory influence on OFF-ganglion cells; hence their discharge rate would increase. This would apply for both direct inhibition (Fig. $1 B$ ) and for inhibition with an amacrine cell interposed (Fig. 1C). So far, this agrees with the results presented above. Moreover, the time course of APB action at ON-bipolar cells should be reflected in $\mathrm{ON}$ - and OFF-ganglion cells, but with an inverse relationship. This is the case: both ON- and OFF-ganglion cells show a biphasic reaction to APB (see Fig. 6) but with exactly opposite polarity.

What could be the transmitter used by the ON-pathway to inhibit OFF-ganglion cells? The uptake of glycine by $10-12 \%$ of bipolar cells and $45 \%$ of amacrine cells suggests that this amino acid might mediate this inhibition. In Results, it was shown that ganglion cell responses are inhibited by exogenous glycine and that this action can be completely blocked by strychnine. Application of strychnine in the absence of exogenous glycine raised the discharge rate of all ganglion cells. Therefore, it is quite likely that they are under the steady influence of endogenous glycine. But the crucial experiment is the interaction between APB and strychnine. If the ON-channel is really inhibiting OFF-ganglion cells using glycine as transmitter, strychnine should be able to block this pathway, and the modulation of ON-bipolar cells by APB should no longer affect OFF-ganglion cells. This has been shown in Results: both the increase and decrease of OFF-ganglion cell responses during the course of APB application are blocked by strychnine.

We therefore propose that, in the cat retina, APB acts as in mudpuppy and rabbit, specifically at ON-bipolar cells. ONbipolar cells have an excitatory input to ON-ganglion cells, but a glycinergic inhibitory influence on OFF-ganglion cells. The results presented in this paper are consistent with a dircet glycinergic inhibition of ON-bipolar cells onto OFF-center gan-
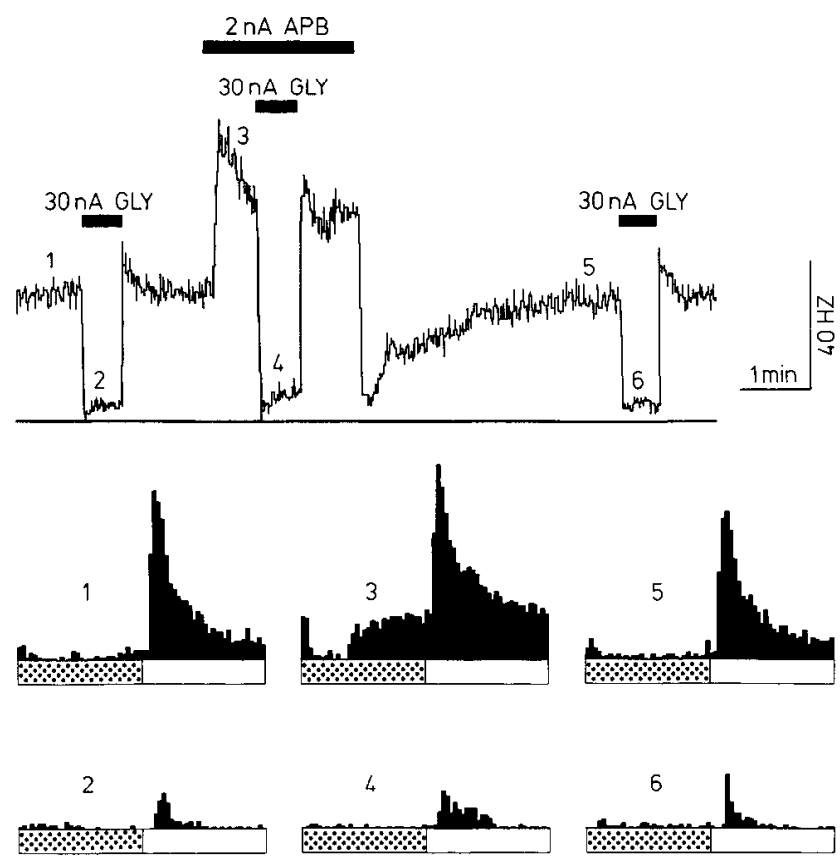

Figure 10. The influence of glycine (GLY) and APB upon the discharge rate of an OFF-center brisk-sustained (X) cell during light stimulation. Conventions as in Figure 4. APB and glycine were retained with a holding current of $13 \mathrm{nA}$. The light spot projected onto the receptive field center had a diameter of $1^{\circ}$ and a luminance of $3 \mathrm{~cd} / \mathrm{m}^{2}$ on a background of $2 \mathrm{~cd} / \mathrm{m}^{2}$. The receptive field center diameter was $1.5^{\circ}$; eccentricity, $11^{\circ}$. 
glion cells (Fig. $1 B$ ) and also with an indirect inhibition, where glycinergic amacrine cells would be interposed (Fig. 1C).

\section{Critical account of the ioniophoresis method}

Our iontophoresis electrode was recording ganglion cell spikes in the inner plexiform layer (IPL) (Bolz et al., 1985a, b). One might argue that it is unlikely that APB diffuses as far as the outer plexiform layer (OPL). However, the above-mentioned studies in mudpuppy and rabbit (Bloomfield and Dowling, 1985a, b; Slaughter and Miller, 1981), where APB was used in concentrations of $100 \mu \mathrm{M}$, superfusing the retinal eyecup, demonstrate that the drug can diffuse from the vitreal side of the retina to the OPL.

Another problem with iontophoresis is the relatively high concentration of drug in the barrel from which an unknown concentration is ejected by current application. We used concentrations between $10 \mathrm{~mm}$ and $1 \mathrm{M}$ APB, which gave qualitatively similar effects. However, low concentrations of APB required high currents and produced relatively little effect, while high concentrations tended to block all $\mathrm{ON}$-center ganglion cells by passive diffusion from the electrode. Therefore, in the present experiments, $100 \mathrm{~mm}$ APB was used, ejection currents as small as $10 \mathrm{nA}$ produced clear results, and retaining currents of about $10 \mathrm{nA}$ stopped passive leakage. The first study in which APB was reported to interfere with the glutamate receptor was performed at the locust neuromuscular junction (Cull-Candy et al., 1976). That study combined physiological iontophoresis experiments on both glutamate and APB with pharmacological binding studies. Iontophoresis of APB, which, as in the present study, was used at a concentration of $100 \mathrm{~mm}$, inhibited the physiological action of glutamate. When measured, the effect of APB on glutamate binding was that it behaved as a competitive inhibitor at concentrations of 10-50 $\mu \mathrm{M}$. While the retina and the insect neuromuscular junction cannot be directly compared, this experiment legitimized iontophoresis as a useful tool, although the concentration differences between APB in the electrode $(100 \mathrm{~mm})$ and in the binding study $(10-50 \mu \mathrm{M})$ were orders of magnitude different. One should bear in mind that only a small fraction of the iontophoresis current actually transports APB ions and also that diffusion from the electrode tip to the site of action further reduces the actual concentration.

There remains the possibility that APB might also act on synapses of the IPL, thus producing the effects we have described. It has been shown by intraccllular recordings from superfused eyecup preparations, both in mudpuppy and rabbit, that at concentrations as low as $50 \mu \mathrm{M}, \mathrm{APB}$ blocked $\mathrm{ON}$-bipolar light responses, but did not have a significant direct action on other neurons in concentrations up to $1 \mathrm{~mm}$ (Bloomfield and Dowling, 1985a, b; Slaughter and Miller, 1981, 1985). In the rabbit retinal eyecup preparation, during extracellular recording from ganglion cells, superfusion with $200 \mu \mathrm{M}$ APB abolished the $\mathrm{ON}$-response of ganglion cells, while the OFF-response increased in size (Neal et al., 1981). The same concentration also abolished the b-wave of the electroretinogram (ERG). Massey et al. (1983) also applied APB at a concentration of $100 \mu \mathrm{M}$ to the rabbit eyecup preparation and observed a block of ONcenter ganglion cells, whereas OFF-center ganglion cells were excited. They presented evidence that the excitation of OFFcenter cells by APB is not a direct action of APB on the ganglion cell membrane, but the result of a transsynaptic network action. They also described how APB abolished the b-wave of the electroretinogram, which therefore seems to be a good indicator of APB action in the retina. It was recently shown that increasing the concentration of APB from $100 \mu \mathrm{M}$ to $1.5 \mathrm{~mm}$ (Knapp and Schiller, 1984), or even up to $16 \mathrm{~mm}$ (Merigan, 1984), abolished mainly the b-wave of the ERG.

The single-cell recordings from rabbit ganglion cells with APB concentrations of $100-200 \mu \mathrm{M}$ gave results qualitatively similar to those of our iontophoresis experiments. Both intracellular recordings and the ERG studies have shown that APB concentration is not too critical. Therefore, it is quite likely that the direct action of APB in our iontophoresis experiments is confined to the ON-bipolar cell in the OPL.

There is good evidence from intracellular recordings in the mudpuppy retina that ganglion cells receive a direct inhibitory input (Belgum et al., 1982; Frumkes et al., 1981). Therefore, it is possible that in the cat retina, ganglion cell responses might result from excitatory and inhibitory inputs, and that the inhibitory ON-OFF interaction postulated in the present paper actually exists.

\section{Glycine uptake and glycinergic inhibition}

An excellent recent review of glycine as a neurotransmitter in the retina (Marc, 1985) included discussions of high-affinity uptake, metabolism, release, and receptor binding and thus these topics need not be covered in this paper. It has recently become possible to raise antibodies against ubiquitously occurring amino acids by coupling them with glutaraldehyde to bovine serum albumin (Storm-Mathisen et al., 1983). Such an approach has been used to raise antibodies to glycine, which has enabled immunocytochemical staining of the cat retina (Goebel and Pourcho, 1985). Amacrine cells and bipolar cells were found to be labeled, confirming results from the uptake studies of ${ }^{3} \mathrm{H}$ glycine.

This study and the analysis of glycine content in monkey retina (Berger et al., 1977) make it very likely that not only is glycine taken up by certain bipolar and amacrine cells, but that glycine is endogenous to those cells and might be used as a transmitter.

In cat retina, AII amacrine cells, which accumulate ${ }^{3} \mathrm{H}$-glycine, have extensive gap junctions with cone bipolar cells (Kolb and Famiglietti, 1974; Pourcho and Goebel, 1985). It has recently been argued (Cohen and Sterling, 1985) that glycine may enter bipolar cells via those gap junctions. While this possibility cannot be excluded, it seems unlikely that a transmitter used in one neuron spills over to a neighboring neuron, which uses a different transmitter.

In a previous study, we compared the physiological action of taurine and glycine (Bolz et al., 1985a). All ganglion cells are suppressed by both glycine and taurine; this can reliably be blocked by strychnine. Therefore, taurine and not glycine might be the actual inhibitory transmitter used. An uptake of ${ }^{3} \mathrm{H}$ taurine strongly labeled mostly photoreceptor cells in the outer retina, which makes it unlikely to be a transmitter candidate for the inner retina (Bolz et al., 1985a).

One might argue that strychnine acts not only by blocking the glycine receptor, but through some additional effects, which might be different for ON- or OFF-center ganglion cells. Strychnine increased the firing rate of all ganglion cell classes, irrespective of type. This is consistent with the idea that it blocks the action of internal glycine, which was found to inhibit all ganglion cells (Bolz et al., 1985a). Strychnine did not interfere with GABAergic inhibition, which was blocked by bicuculline.

Only when strychnine was used in addition to APB were differences between $\mathrm{ON}$ - and OFF-center ganglion cells observed. They might be explained by the scheme in Figure 1 without postulating convoluted multineuron models or strychnine actions that differed from its well-known blockage of the glycine receptor.

\section{References}

Abercrombie, M. (1946) Estimation of nuclear population from microtome sections. Anatom. Rec. 94: 239-247.

Belgum, J. H., D. R. Dvorak, and J. S. McReynolds (1982) Sustained synaptic input to ganglion cells of mudpuppy retina. J. Physiol. (Lond.) 326: 91-108.

Berger, S. J., M. L. McDaniel, J. G. Carter, and O. H. Lowry (1977) 
Distribution of four potential transmitter amino acids in monkey retina. J. Neurochem. 28: 159-163.

Bloomfield, S. A., and J. E. Dowling (1985a) Roles of aspartate and glutamate in synaptic transmission in rabbit retina. I. Outer plexiform layer. J. Neurophysiol. 53: 699-713.

Bloomfield, S. A., and J. E. Dowling (1985b) Roles of aspartate and glutamate in synaptic transmission in rabbit retina. II. Inner plexiform layer. J. Neurophysiol. 53: 714-725.

Bolz, J., T. E. Frumkes, T. Voigt, and H. Wässle (1985b) Action and localisation of gamma-aminobutyric acid in the cat retina. J. Physiol (Lond.) 362: 369-393.

Bolz, J., G. Rosner, and H. Wässle (1982) Response latency of brisksustained (X) and brisk-transient (Y) cells in the cat retina. J. Physiol. (Lond.) 328: 171-190.

Bolz, J., P. Thier, T. Voigt, and H. Wässle (1985a) Action and localisation of glycine and taurine in the cat retina. J. Physiol. (Lond.) 362 : 395-413.

Bolz, J., H. Wässle, and P. Thier (1984) Pharmacological modulation of ON and OFF ganglion cells in the cat retina. Neuroscience 12 : $875-885$.

Boycott, B. B., and I. M. Hopkins (1981) Microglia in the retina of monkey and other mammals; its distinction from other types of glia and horizontal cells. Neuroscience 6: 679-688.

Boycott, B. B., and H. Kolb (1973) The connection between bipolar cells and photoreceptors in the retina of the domestic cat. J. Comp. Neurol. 148: 91-114.

Boycott, B. B., J. E. Dowling, S. K. Fisher, H. Kolb, and A. M. Laties (1975) Interplexiform cells of the mammalian retina and their comparison with catecholamine-containing retinal cells. Proc. R. Soc. Lond. [Biol.] 191: 353-368.

Boycott, B. B., L. Peichl, and H. Wässle (1978) Morphological types of horizontal cells in the retina of the domestic cat. Proc. R. Soc. Lond. [Biol.] 203: 229-245.

Bruun, A., and B. Ehinger (1972) Uptake of the putative neurotransmitter, glycine, into the rabbit retina. Invest. Ophthalmol. Vis. Sci. 11: 191-198.

Cleland, B. G., and W. R. Levick (1974a) Brisk and sluggish concentrically organized ganglion cells in the cat's retina. J. Physiol. (Lond.) 240: 421-456.

Cleland, B. G., and W. R. Levick (1974b) Properties of rarely encountered types of ganglion cells in the cat's retina and an overall classification. J. Physiol. (Lond.) 240: 457-492.

Cohen, E., and P. Sterling (1985) Glycine accumulation by cone bipolar neurons in the cat retina. Invest. Ophthalmol. Vis. Sci. 26: 95.

Cull-Candy, S. G., J. F. Donellan, R. W. James, and G. G. Lunt (1976) 2-Amino-4-phosphonobutyric acid as a glutamate antagonist on locust muscle. Nature 262: 408-409.

Ehinger, B., and B. Falck (1971) Autoradiography of some suspected neurotransmitter substances: GABA, glycine, glutamic acid, histamine, dopamine, and L-DOPA. Brain Res. 33: 157-172.

Famiglietti Jr., E. V. (1981) Functional architecture of cone bipolar cells in mammalian retina. Vision Res. 21: 1559-1563.

Frederick, J. M., M. E. Rayborn, and J. G. Hollyfield (1984) Glycinergic neurons in the human retina. J. Comp. Neurol. 227: 159-172.

Frumkes, T. E., R. F. Miller, M. Slaughter, and R. F. Dacheux (1981) Physiological and pharmacological basis of GABA and glycine action on neurons of mudpuppy retina. III. Amacrine-mediated inhibitory influences on ganglion cell receptive field organization: A model. J. Neurophysiol. 45: 783-804.

Goebel, D. J., and R. G. Pourcho (1985) Immunocytochemical visualization of glycine in cat retina. Invest. Ophthalmol. Vis. Sci. 26: 95.

Horton, J. C., and H. Sherk (1984) Receptive field properties in the cat's lateral geniculate nucleus in the absence of on-center retinal input. J. Neurosci. 4: 374-380.

Kleinschmidt, J., and S. Yazulla (1984) Uptake of ${ }^{3} \mathrm{H}-$ Glycine in the outer plexiform layer of the retina of the toad, Bufo marinus. J. Comp. Neurol. 230: 352-360.

Knapp, A. G., and P. H. Schiller (1984) The contribution of ONbipolar cells to the electroretinogram of rabbits and monkeys. Vision Res. 24: 1841-1846.

Kolb, H. (1977) The organisation of the outer plexiform layer in the retina of the cat: Electron microscopic observations. J. Neurocytol. 6: 131-153.

Kolb, H., and E. V. Famiglietti (1974) Rod and cone pathways in the inner plexiform layer of the cat retina. Science 186: 47-49.
Kolb, H., and R. Nelson (1981) Amacrine cells of the cat retina. Vision Kes. 21: 1625-1633.

Kolb, H., and R. Nelson (1983) Rod pathways in the retina of the cat. Vision Res. 23: 301-312.

Kolb, H., and R. West (1977) Synaptic connections of the interplexiform cell in the retina of the cat. J. Neurocytol. 6: 155-170.

Kolb, H., R. Nelson, and A. Mariani (1981) Amacrine cells, bipolar cells and ganglion cells of the cat retina: A Golgi study. Vision Res. 21: $1081-1114$.

Lee, C. M., and L. L. Iversen (1981) Release of somatostatin from extra-hypothalamic rat brain slices: Inhibition by dopamine and morphine. Brain Res. 219: 355-361.

Levick, W. R. (1972) Another tungsten microelectrode. Med. Biol. Eng. 10: 510-515.

Marc, R. E. (1982) Spatial organization of neurochemically classified interneurons in the goldfish retina. I. Local patterns. Vision Res. 22 : $589-608$.

Marc, R. E. (1985) The role of glycine in retinal circuitry. In Retinal Transmitters and Modulators: Models for the Brain, W. W. Morgan, ed., Vol. 1, pp. 119-158, CRC Press, Boca Raton, FL.

Marc, R. F., and D. M.-K. Lam (1981) Glycinergic pathways in the goldfish retina. J. Neurosci. 1: 152-165.

Marc, R. E., and W.-L. S. Liu (1984) Horizontal cell synapses onto glycine-accumulating interplexiform cells. Nature 312: 266-269.

Marc, R. E., and W.-L.S. Liu (1985) ( $\left.{ }^{3} \mathrm{H}\right)$ glycine-accumulating neurons of the human retina. J. Comp. Neurol. 232: 241-260.

Marshall, J., and M. Voaden (1974) An investigation of cells incorporating $\left({ }^{3} \mathrm{H}\right) \mathrm{GABA}$ and $\left({ }^{3} \mathrm{H}\right)$ glycine in the isolated retina of the rat. Exp. Eye Res. 18: 367-370.

Massey, S. C., D. A. Redburn, and M. L. J. Crawford (1983) The effects of 2-amino-4-phosphonobutyric acid (APB) on the ERG and ganglion cell discharge of rabbit retina. Vision Res. 23: 1607-1613.

McGuire, B. A., J. K. Stevens, and P. Sterling (1980) Beta ganglion cells receive convergent input from 2 types of cone bipolar cells. Soc. Neurosci. Abstr. 6: 347

McGuire, B. A., J. K. Stevens, and P. Sterling (1984) Microcircuitry of bipolar cells in cat retina. J. Neurosci. 4: 2920-2938.

McGuire, B. A., J. K. Stevens, and P. Sterling (1985) Microcircuitry of the beta ganglion cell. J. Neurosci. 5 .

Merigan, W. H. (1984) APB effects on primate ERG. Invest. Ophthalmol. Vis. Sic. 25: 259 .

Nakamura, Y., B. A. McGuire, and P. Sterling (1980) Interplexiform cell in cat retina: Identification by uptake of gamma- $\left({ }^{3} \mathrm{H}\right)$ aminobutyric acid and serial reconstruction. Proc. Natl. Acad. Sci. USA 77: 658661.

Neal, M. J., J. R. Cunningham, T. A. James, M. Joseph, and J. F. Collings (1981) The effect of 2-amino-4-phosphonobutyrate (APB) on acetylcholine release from the rabbit retina: Evidence for on-channel input to cholinergic amacrine cells. Neurosci. Lett. 26: 301-305.

Nelson, R., and H. Kolb (1983) Synaptic patterns and response properties of bipolar and ganglion cells in the cat retina. Vision Res. 23: 1183-1195.

Peichl, L., and H. Wässle (1979) Size, scatter and coverage of ganglion cell receptive field centres in the cat retina. J. Physiol. (Lond.) 291: 117-141.

Peichl, L., and H. Wässle (1983) The structural correlate of the receptive field centre of alpha ganglion cells in the cat retina. J. Physiol. (Lond.) 341: 309-324.

Polley, E. H., and C. Walsh (1984) A technique for flat embedding and en face sectioning of the mammalian retina for autoradiography. J. Neurosci. Methods 12: 57-64.

Polyak, S. (1941) The Retina, University of Chicago Press, Chicago.

Pourcho, R. G. (1980) Uptake of $\left({ }^{3} \mathrm{H}\right)$ glycine and $\left({ }^{3} \mathrm{H}\right) \mathrm{GABA}$ by amacrine cells in the cat retina. Brain Res. 198: 333-346.

Pourcho, R. G., and D. J. Goebel (1983) Neuronal subpopulations in cat retina which accumulate the GABA agonist, $\left({ }^{3} \mathrm{H}\right)$ muscimol: A combined golgi and autoradiographic study. J. Comp. Neurol. 219: 25-35.

Pourcho, R. G., and D. J. Goebel (1985) A combined golgi and autoradiographic study of $\left({ }^{3} \mathrm{H}\right)$ glycine-accumulating amacrine cells in the cat retina. J. Comp. Neurol. 233: 473-480.

Schmidt, M., H. Wässle, and M. Humphrey (1985) Number and distribution of putative cholinergic neurons in the cat retina. Neurosci. Lett. 59: 235-240.

Sherk, H., and J. C. Horton (1984) Receptive field properties in the 
cat's area 17 in the absence fon-center geniculate input. J. Neurosci. 4: 381-393.

Slaughter, M. M., and R. F. Miller (1981) 2-Amino-4-phosphonobutyric acid: A new pharmacological tool for retina rescarch. Science 211: 182-185.

Slaughter, M. M., and R. F. Miller (1985) Characterization of an extended glutamate receptor of the on bipolar neuron in the vertebrate retina. J. Neurosci. 5: 224-233.

Steinberg, R. H., M. Reid, and P. L. Lacy (1973) The distribution of rods and cones in the retina of the cat (Felis domesticus). J. Comp. Neurol. 148: 229-248.

Sterling, P. (1983) Microcircuitry of the cat retina. Annu. Rev. Neurosci. 6: 149-185.
Storm-Mathisen. H., A. K. Leknes, A. T. Bore, J. L. Vaaland, P. Edminson, F.-M. S. Haug, and O. P. Ottersen (1983) First visualization of glutamate and GABA in neurons by immunocytochemistry. Nature 301: $517-520$.

Vaney, D. I. (1985) The morphology and topographic distribution of AII amacrine cells in the cat retina. Proc. R. Soc. Lond. [Biol.] 224: $475-488$.

Wässle, H., L. Peichl, and B. B. Boycott (1978) Topography of horizontal cells in the retina of the domestic cat. Proc. R. Soc. Lond. [Biol.] 203: 269-291. 